\title{
SISTEM INFORMASI PENGELOLAAN BARANG PERSEDIAAN MILIK NEGARA DI PUSAT PENILAIAN PENDIDIKAN
}

\section{Information System for State Inventory Management at Education Assessment Center}

\author{
Erwin Suhandono ${ }^{1 *}$ dan Arif Hidayat ${ }^{2}$ \\ ${ }^{1}$ Universitas Persada Indonesia YAI Jakarta, Jl Salemba Raya no 7-9 Jakarta Pusat 10340, Indonesia \\ ${ }^{2}$ Universitas Pancasila Jakarta, Jl Srengseng Sawah Jagakarsa Jakarta Selatan 12640, Indonesia
}

\section{Informasi artikel}

Diterima: 05/01/2020

Direvisi : 10/01/2020

Disetujui: $20 / 01 / 2020$

\begin{abstract}
Abstrak
Pusat Penilaian Pendidikan merupakan Instansi Pemerintah dibawah Badan Penelitian dan Pengembangan Kementerian Pendidikan dan Kebudayaan dalam melakukan kegiatan pencatatan persediaan barang masih manual dengan standarisasi yang diberikan. Hal ini perlu dilakukan perbaikan dalam pengelolaan barang persediaan milik pemerintah dan bertujuan untuk dapat meningkatkan efektivitas dan akurasi data yang lebih baik sehingga dalam proses pengolahannya tidak membutuhkan waktu yang lama. Berdasarkan permasalahan tersebut maka diperlukan sebuah sistem informasi secara digitalisasi, sehingga dapat menginformasikan jumlah barang yang tersedia. Sistem informasi ini dirancang dengan berdasarkan Object Oriented (Berorientasi Objek) dengan menggunakan Unified Modeling Language (UML). Hasil dari aplikasi yang dibangun berdasarkan pengujian alpha adalah secara fungsionalitas mengeluarkan hasil yang sesuai dengan yang diharapkan dan berdasarkan pengujian betha menurut responden, aplikasi sesuai kebutuhan dan berjalan dengan baik.
\end{abstract}

Kata Kunci: pengolahan barang persediaan, sistem informasi, unified modeling language.

\begin{abstract}
The center of the assessment of education is an and agencies administering the program the government under research and development education and culture ministry in attending to the duties of activities in defiance of a an inventory of goods use the standardization made by who diberikan.hal is clearly necessary refinement in a buildup in inventories can logistics management system handed over to the government and are meant to be able to enhance its effectiveness and the accuracy of the data better so as to be in the process of processing industry for the plantation do not need a long time. Based on these problems he or she needs a system digitalisasi fact that the information is, so that it can be had informed islamabad of the amount of goods that are available. An integrated information system for this has been designed by virtue of object oriented by the use of the unified modeling language (uml). The results of of the application to aim to build upon some testing alpha is it should also be noted the requested functionality yield its fruit that corresponds to an less than hoped for while based on testing betha according to respondents, the application as needed and it goes well.
\end{abstract}

Keywords: inventory processing, information systems, unified modeling language. 


\section{PENDAHULUAN}

Dewasa ini perkembangan teknologi berkembang dengan sangat cepat sehingga mendorong untuk mengikuti perkembangan zaman yang serba menggunakan teknologi tersebut. Seperti halnya dalam pengelolaan barang persediaan milik negara di lingkungan Pusat Penilaian Pendidikan (Puspendik) Badan Penelitian dan Pengembangan Kementerian Pendidikan dan Kebudayaan dimana sebelumnya dilakukan secara manual yaitu setiap masuk keluarnya barang persediaan dilakukan pencatatan dengan tulisan tangan pada kertas yang telah distandarisasi.

Cara ini memiliki beberapa kekurangan diantaranya yaitu memerlukan waktu yang relatif lebih lama, rentan hilang atau rusaknya berkas, keakuratan data yang kurang serta sulit dalam melakukan pengolahan data barang persediaan tersebut. Maka dari itu untuk meningkatkan efisiensi dan mutu pengelolaan barang persediaan milik negara perlu dilakukan dengan proses pengelolaan dengan bantuan teknologi salah satunya yaitu menggunakan aplikasi berbasis web.

Barang persediaan milik negara adalah aset lancar dalam bentuk barang atau perlengkapan yang dimaksudkan untuk mendukung kegiatan operasional pemerintah, dan barang-barang yang dimaksudkan untuk dijual dan/atau diserahkan dalam rangka pelayanan dalam masyarakat. Mengingat banyaknya penggunaan barang persediaan baik itu secara kuantitas maupun secara nilai peroleh yang tinggi maka diperlukan peningkatan pengelolaan yang baik. Sehingga memudahkan dalam menghitung jumlah persediaan barang yang dibutuhkan, memudahkan pencatatan pendistribusian dan membuat laporan keuangan barang persediaan milik negara di akhir tahun lebih cepat dan tepat dalam penyajiannya.

Untuk mewujudkan pengelolaan barang persediaan milik negara di lingkungan Pusat Penilaian Pendidikan dengan baik dan benar. Maka dibuatkan suatu aplikasi pengelolaan database berbasis web. Hal ini bertujuan untuk dapat meningkatkan efektivitas dan akurasi data yang lebih bagus dalam pengelolaan barang persediaan tersebut. Aplikasi ini akan mengintegrasikan antar pengelola, pimpinan, pengguna dan penyedia barang sehingga terjadi komunikasi yang lebih tepat waktu walaupun antar users tersebut tidak saling bertatap muka seperti halnya proses manual dengan pencatatan pada kertas. Menu-menu yang tersaji pada aplikasi ini ditampilkan sesuai dengan kebutuhan penggunanya.

Adapun tujuan dari penelitian ini yaitu membangun Sistem Informasi Pengelolaan Barang Persediaan Milik Negara di Pusat Penilaian Pendidikan yang bermanfaat untuk:

1) Merealisasikan program digitalisasi sistem barang persediaan di Pusat Penilaian Pendidikan.

2) Mengelolah data barang masuk, barang keluar, barang return dan penghapusan barang rusak berat di Pusat Penilaian Pendidikan.

3) Membuat sistem yang dapat melakukan pengontrolan stok barang persediaan sehingga dapat menginformasikan tentang jumlah stok barang yang ada di gudang.

4) Dapat menunjang kinerja di Lingkungan Pusat Penilaian Pendidikan untuk pengembangan sistem terkomputerisasi yang dapat digunakan oleh pihak Kementerian.

\section{METODOLOGI}

Penelitian menggunakan studi observasi langsung, dokumentasi maupun wawancara dengan operator serta pihak-pihak yang dapat memberikan informasi yang berhubungan dengan judul penelitian yang sedang dilakukan. Selain itu juga menggunakan Library Research untuk mengumpulkan bahan-bahan melalui bukubuku, artikel dan bahan bacaan lain yang berhubungan dengan pokok pembahasan yang akan dibahas dalam penelitian.

\section{a. Observasi}

Secara umum observasi merupakan suatu teknik atau cara mengumpulkan data dengan mengadakan pengamatan langsung terhadap suatu kegiatan penelitian, bisa berkenaan dengan cara inventarisasi barang persediaan, cara menggunakan barang persediaan, dan bagaimana cara menyimpan barang serta cara membuat laporan keuangan barang persediaan milik negara. Observasi adalah mengamati dan mendengar dalam rangka memahami, mencari jawaban dan mencari bukti terhadap fenomena sosial. Metode ini bermanfaat untuk memperoleh data dengan mengadakan pengamatan selama beberapa waktu tanpa mempengaruhi fenomena yang 
diobservasi dengan mencatat, merekam dan memotret fenomena tersebut guna mendapatkan data untuk dianalisa.

b. Wawancara

Wawancara dapat dipandang sebagai metode pengumpulan data dengan jalan tanya jawab sepihak yang dikerjakan secara sistematis dan berdasarkan kepada tujuan penelitian. Pada umumnya dua orang atau lebih hadir secara fisik dalam proses tanya jawab. Dalam hal ini responden yang dipilih adalah para pengelola data barang persediaan milik negara di lingkungan Puspendik Balitbang Kemdikbud meliputi Kepala Sub bagian Keuangan dan Rumah tangga, Penanggung Jawab Kegiatan, dan Pengelola barang persediaan milik negara. Pegawai yang terlibat dianggap memiliki pengetahuan dan mendalami situasi serta lebih mengetahui informasi yang diperlukan, lebih jelasnya metode ini digunakan untuk memperoleh data tentang peranan teknologi dalam pengelolaan persediaan barang milik negara.

c. Studi Pustaka

Mengumpulkan data yang diperoleh dari buku-buku yang berada diperpustakaan, jurnal-jurnal yang terkait dengan penelitian atau literatur lain yang dapat dijadikan acuan untuk pengembangan sistem persediaan barang milik negara.

\section{HASIL DAN PEMBAHASAN}

\section{Perancangan Sistem}

Perancangan aplikasi Sistem Pegelolaan Barang Persediaan Milik Negara di Pusat Penilaian Pendidikan yang dibangun ini bersifat object-oriented programming (program berorientasi objek) dengan menggunakan Unified Modeling Language (UML) sebagai bahasa pemodelan.

\section{Arsitektur Perangkat Lunak}

Sistem informasi dimulai dari proses input dan menghasilkan output informasi. Penulis merancang dan membangun sistem informasi aplikasi Sistem Pegelolaan Barang Persediaan Milik Negara di Pusat Penilaian Pendidikan dengan arsitektur perangkat lunak seperti Gambar 1.

\section{Pemodelan Sistem}

Pada tahap ini, Unified Modelling Language (UML) yang digunakan untuk membuat pemodelan software dari aplikasi Sistem Pegelolaan Barang Persediaan Milik Negara di Pusat Penilaian Pendidikan yaitu sebagai berikut:

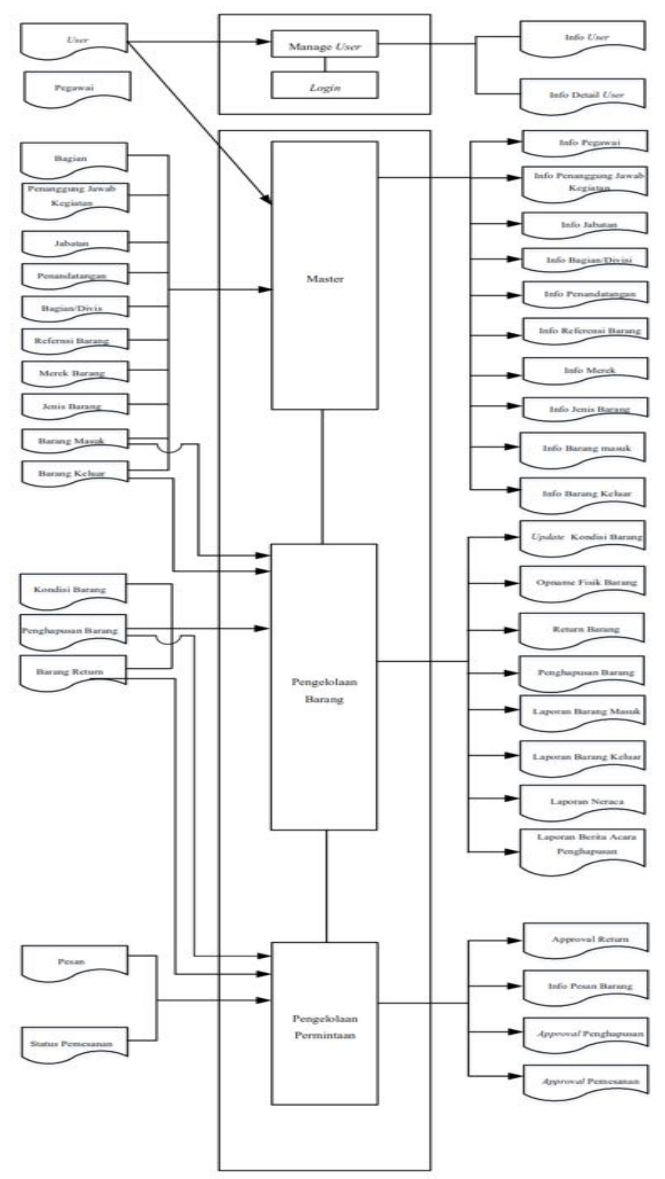

Gambar 1 Arsitektur perangkat lunak

Dari gambar diatas dapat dilihat proses perancangan yang dibuat dalam pengelolaan persediaan barang.

a. Use Case

Model Use Case menjelaskan mengenai aktor- aktor yang terlibat dalam perangkat lunak yang dibangun beserta proses - proses yang ada didalamnya. Berikut ini adalah gambar dari diagram use case pada aplikasi Sistem Pegelolaan Barang Persediaan Milik Negara di Pusat Penilaian Pendidikan seperti pada Gambar 2. Gambar 2 menjelaskan tentang informasi antara beberapa aktor yang terlibat dengan sistem. 


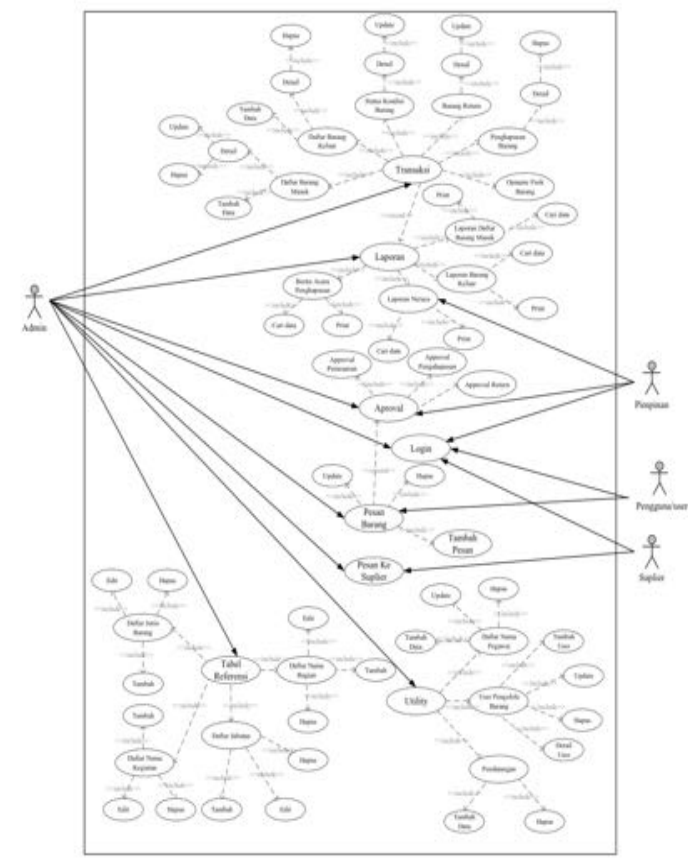

Gambar 2 Use case diagram

b. Activity Diagram

Berikut ini adalah beberapa activity diagram yang terbentuk dari kegiatan bisnis dan diagram use case yang ada pada sistem yang diusulkan, seperti pada Gambar 3 sampai dengan 7.

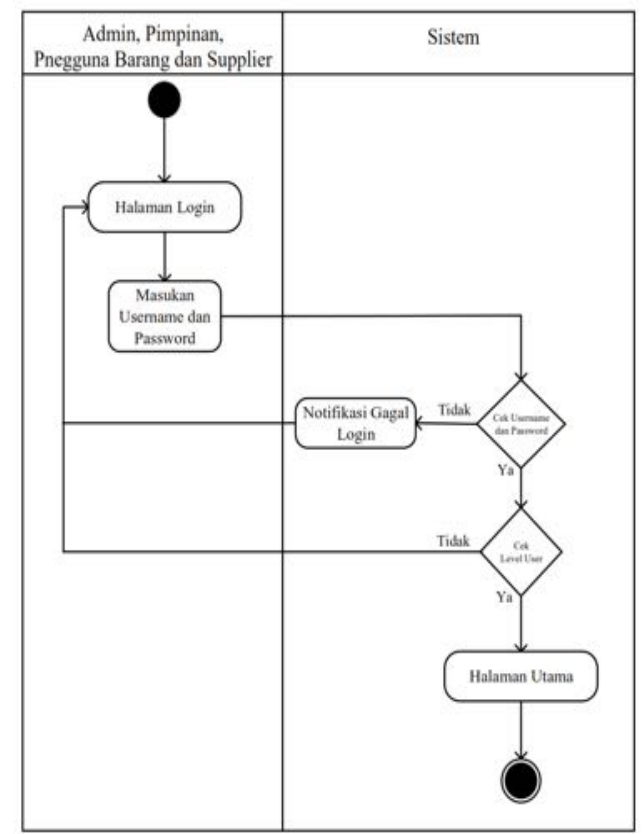

Gambar 3 Activity diagram login

Gambar 3, menerangkan tentang aktifitas login yang dilakukan oleh administrator, pengguna barang dan suplier terhadap sistem.

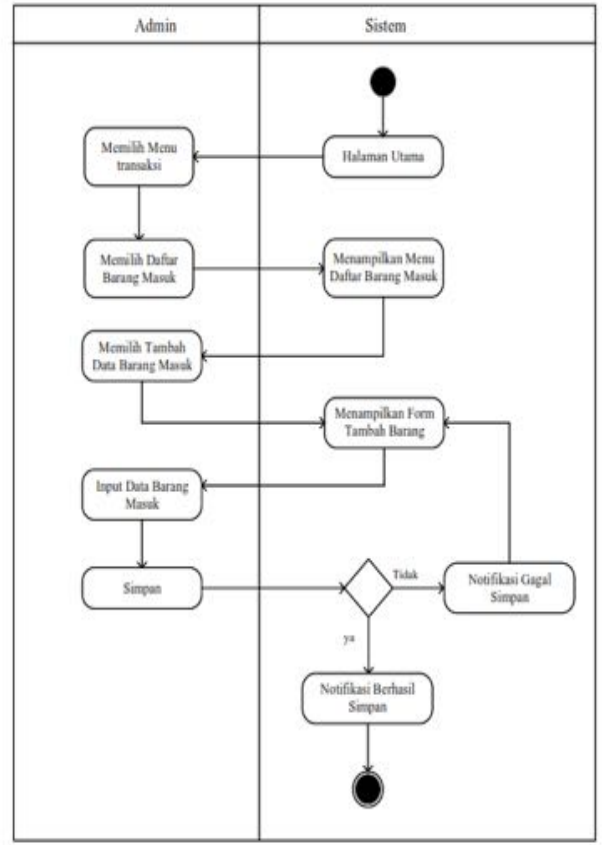

Gambar 4 Activity diagram tambah data barang masuk

Gambar 4 menerangkan tentang aktifitas tambah proses data barang masuk yang dilakukan oleh admin.

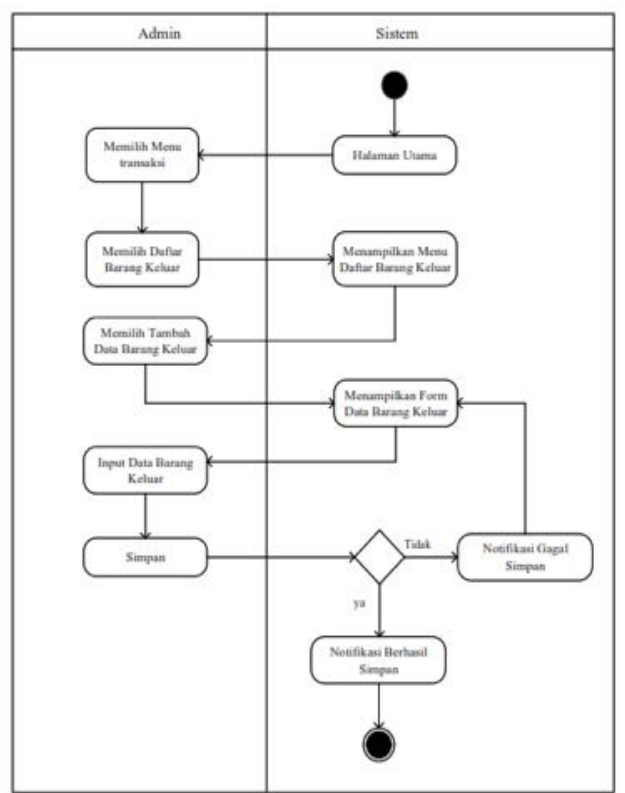

Gambar 5 Activity diagram tambah data barang keluar

Gambar 5 memperlihatkan bahwa apabila ada barang yang keluar maka bisa ditambah melalui aplikasi tersebut. 


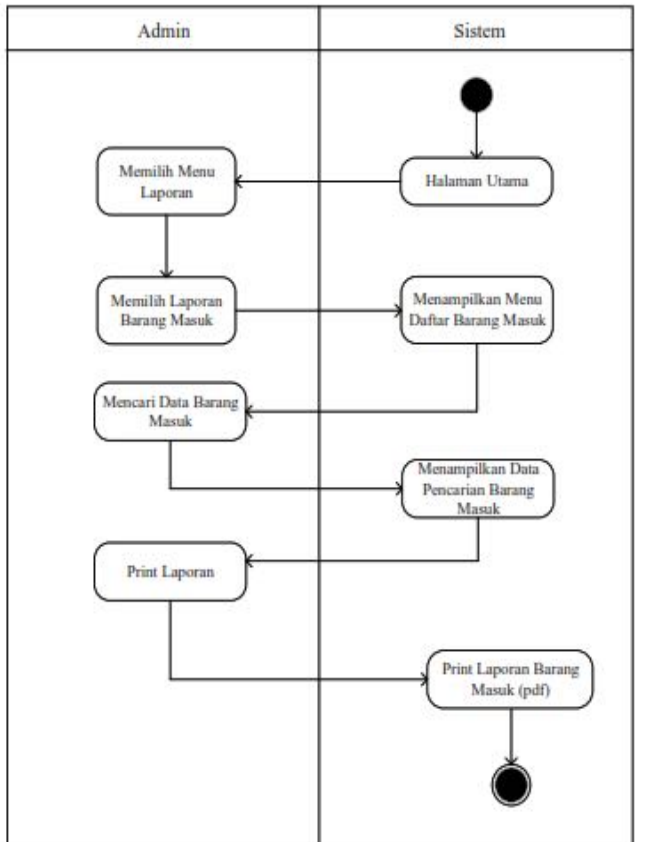

Gambar 6 Activity diagram laporan barang masuk

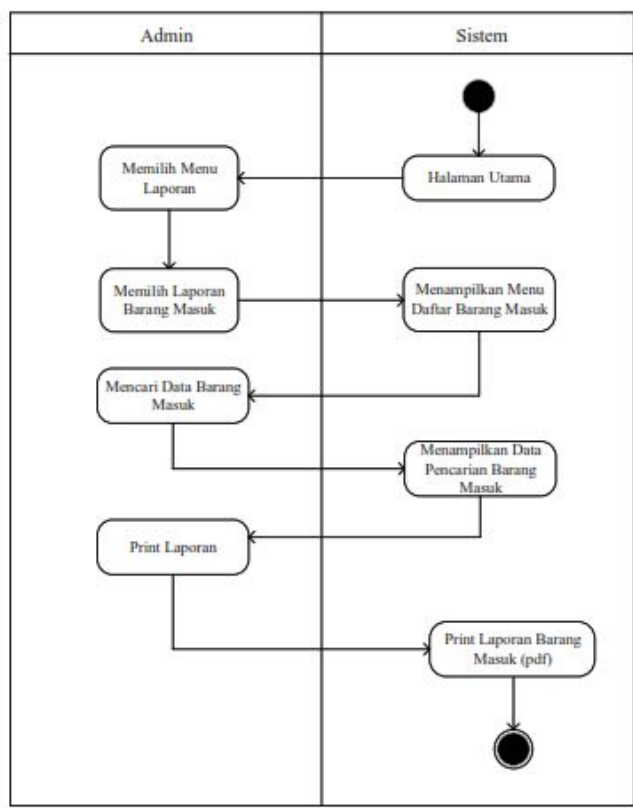

Gambar 7 Activity diagram laporan barang keluar

\section{c. Class Diagram}

Class diagram adalah diagram yang digunakan untuk menampilkan beberapa kelas yang ada dalam sistem perangkat lunak yang akan dikembangkan. Berikut ini gambar class diagram dari aplikasi Sistem Pengelolaan Barang Persediaan Milik Negara di Pusat Penilaian Pendidikan

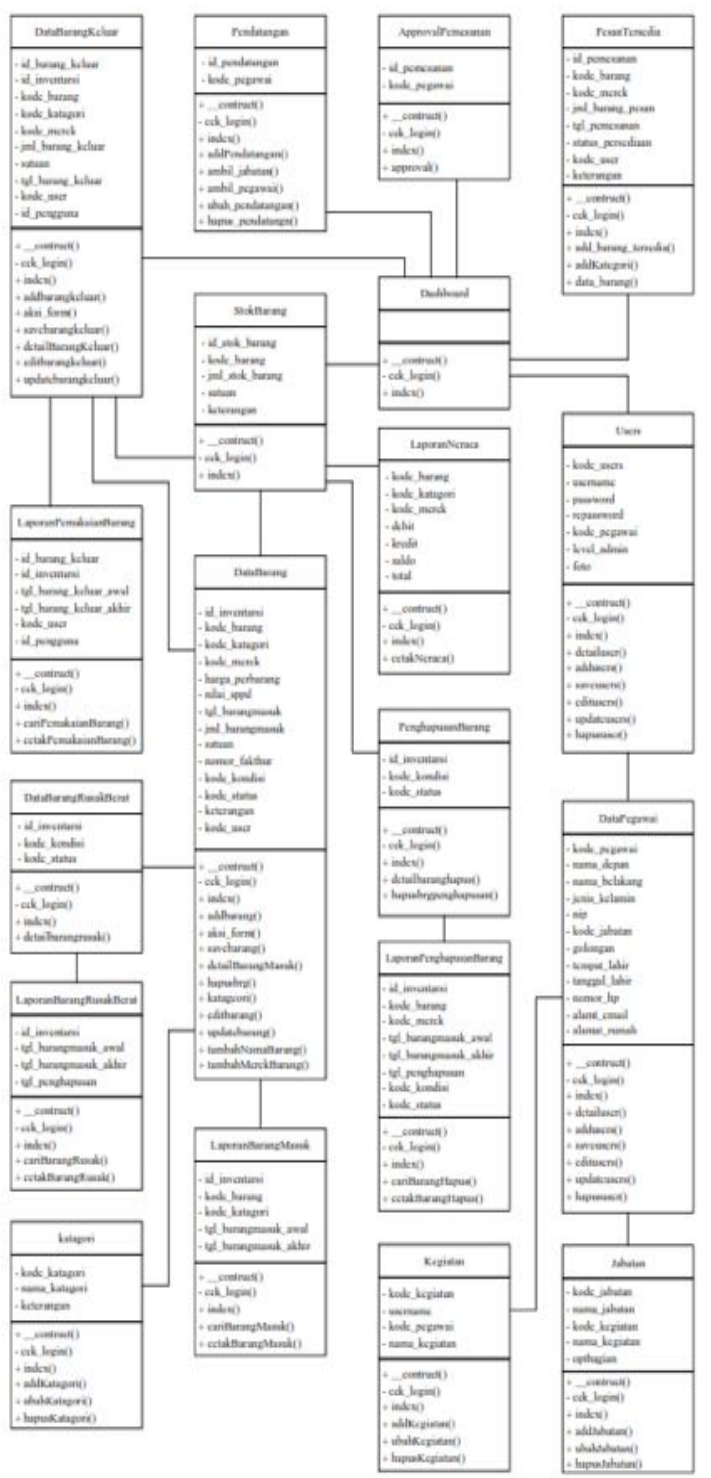

Gambar 8 Class Diagram

d. Sequence Diagram Sequence diagram menggambarkan interaksi antara objek dan mengindikasikan komunikasi anatara objek-objek tersebut.

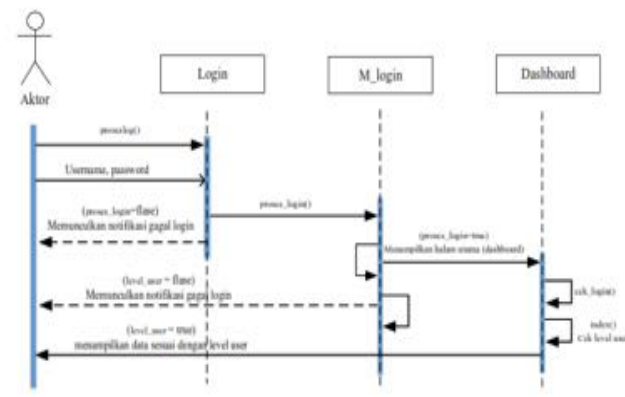

Gambar 9 Sequence diagram login 
Berikut sequence diagram pada aplikasi Sistem Pegelolaan Barang Persediaan Milik Negara di Pusat Penilaian Pendidikan dapat dilihat pada Gambar 9. Sequence Diagram Login menggambarkan aktifitas admin atau user saat masuk ke sistem.

e. Bagan Struktur

Bagan struktur sistem informasi pengelolaan barang persediaan milik negara di pusat penilaian Pendidikan. Bagan Struktur ini menjelaskan tentang struktur aplikasi yang terdapat pada program.

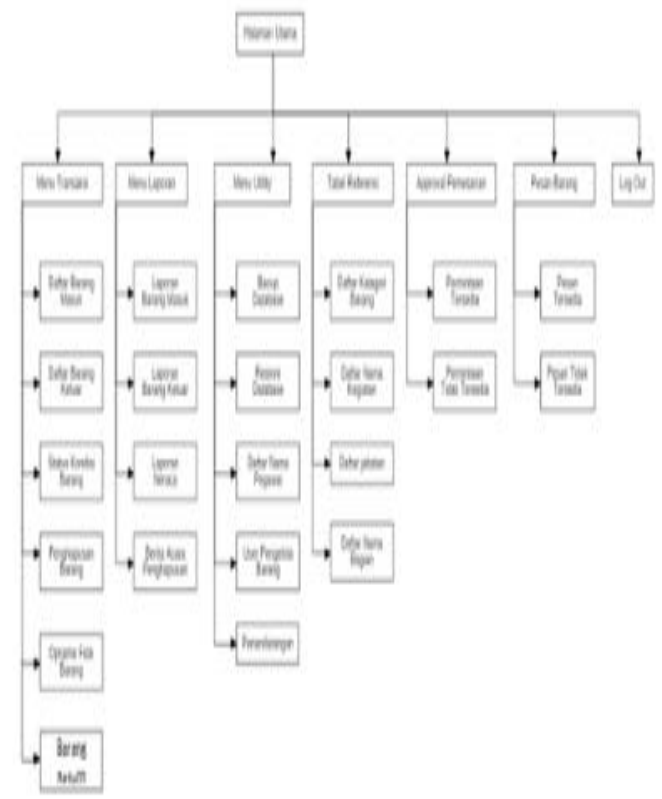

Gambar 10 Bagan struktur aplikasi

f. Perancangan Output

Berikut adalah bentuk form data dari barang masuk dan keluar dapat diliaht pada Gambar 11.

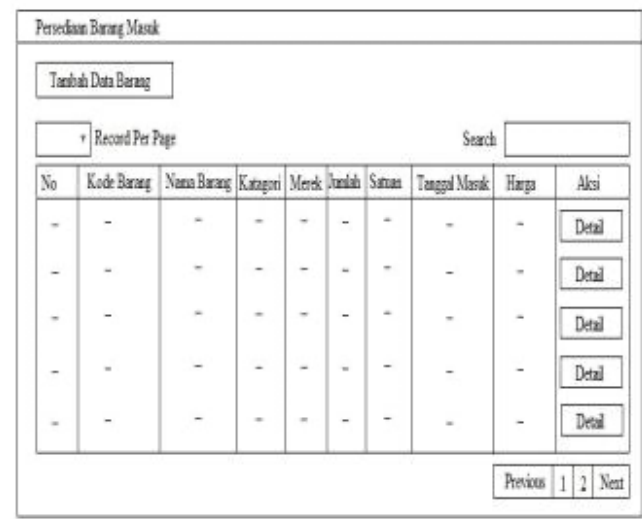

Gambar 11 Perancangan daftar data barang masuk

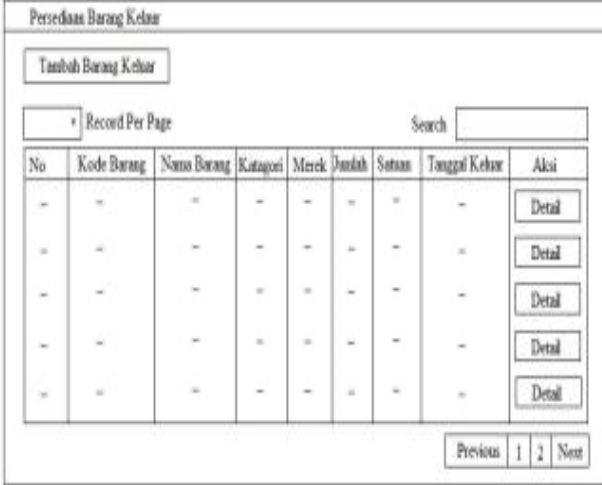

Gambar 12 Perancangan daftar data barang kelaur

Bahwa dari perancangan output diatas dapat dilihat tentang daftar barang yang keluar.

g. Perancangan Input

Berikut adalah tampilan jendela login input Ini adalah menu dimana user melakukan login untuk masuk kedalam sistem

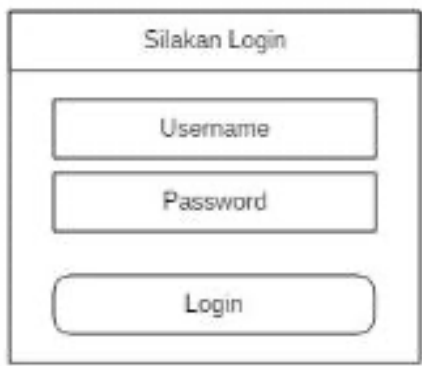

Gambar 13 Perancangan input login

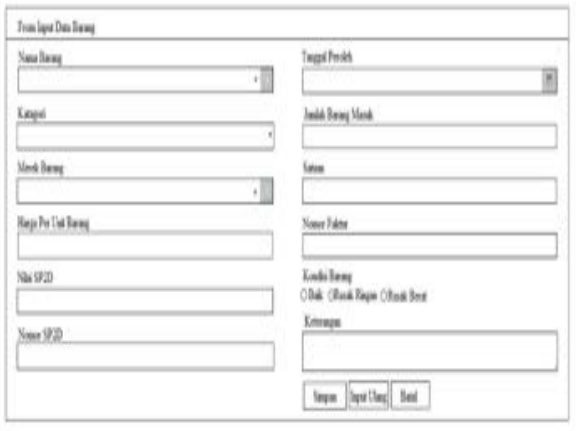

Gambar 14 Perancangan input data barang

Dari Gambar 14 menampilkan tampilan input barang yang masuk ke dalam data base. 


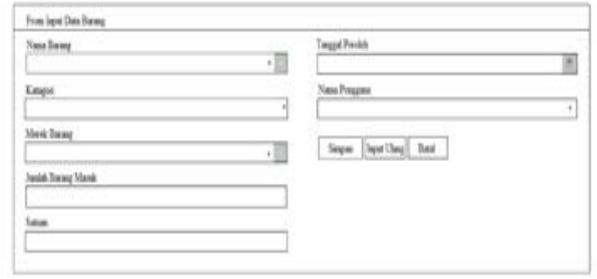

Gambar 15 Perancangan input data barang keluar

h. Implementasi

1) Spesifikasi Perangkat Keras

Perangkat keras yang digunakan untuk aplikasi sistem informasi ini adalah HP240 dengan spesifikasi sebagai berikut:

Tabel 1 Spesifikasi perangkat Lunak

\begin{tabular}{cc}
\hline Processor & Intel (R) Core (TM) i3 \\
Memory RAM & 4.00 GB \\
System Type & 64-bit Operating System \\
\hline
\end{tabular}

2) Spesifikasi Perangkat Lunak

Perangkat lunak yang digunakan untuk aplikasi sistem informasi ini sebagai berikut :

(1). HTML 5

(2). Bootstrap

(3). PHP 5.6.36

(4). Xampp 3.2.2

(5). MySQL 5.0.11

(6). Web Browser Chrome

\section{Implementasi Basis Data}

Pada aplikasi sistem informasi ini membutuhkan database yang terdiri dari 16 tabel yaitu tabel tbl_bagian, tabel tbl_barangmasuk, tabel tbl_barangkeluar, tabel tbl_jabatan, tabel tbl_katagori, tabel tbl_kondisi, tabel tbl_merek, tabel tbl_pegawai, tabel tbl_penandatangan, dan tabel tbl_penghapusan, tabel tbl_pesan, tabel tbl_pjkt, tabel tbl_ref_barang, tabel tbl_status_pemesanan, tabel tbl_stok_ barang, tbl_users sebagai berikut :

\section{//Set variable}

Susername = \$this->input->post('username'); \$nama = \$this->input->post('username'); \$password = \$this->input->post('username'); //cek database \$query = \$this->db->query("SELECT * FROM tbl_uswers

$$
\begin{aligned}
& \text { WHERE username } \\
& \text { ='\$username' AND }
\end{aligned}
$$$$
\text { password = '\$password'”); }
$$

Query untuk menampilkan daftar barang pesanan sesuai dengan level admin dan Id Users pemesan.

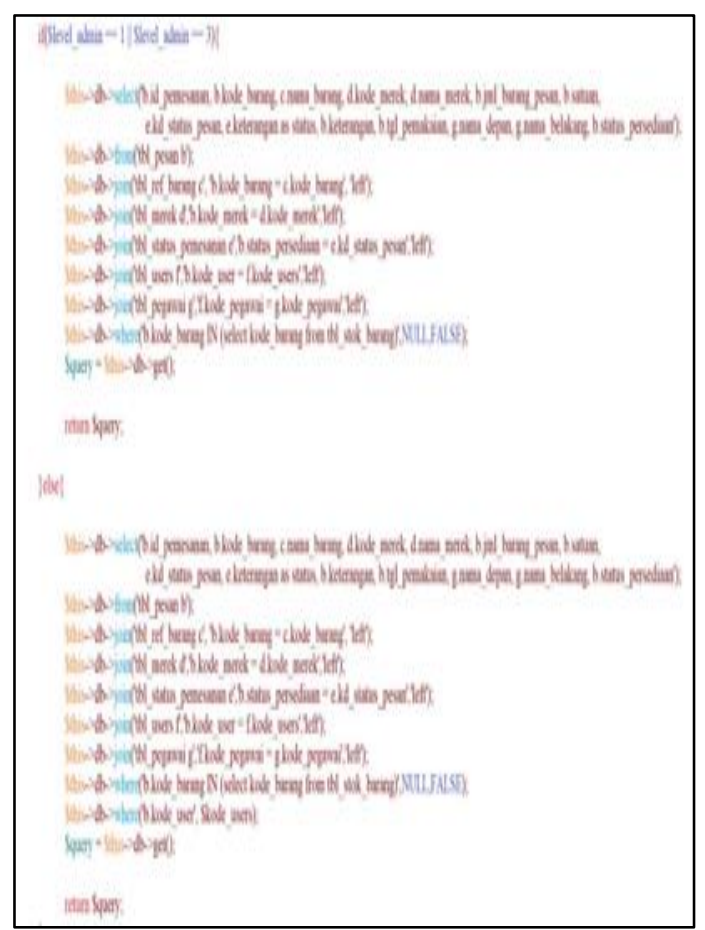

Gambar 16 Query menampilkan daftar barang pesanan sesuai dengan level admin dan Id Users pemesan

Dari gambar diatas dapat kita lihat query barang pesanan sesuai dengan level admin dan id user si pemesan barang.

Query untuk menampilkan daftar barang pesanan ke Supplier diperlihatkan pada Gambar 17 query tentang daftar barang pesanan ke suplier yang dapat ditampilkan.

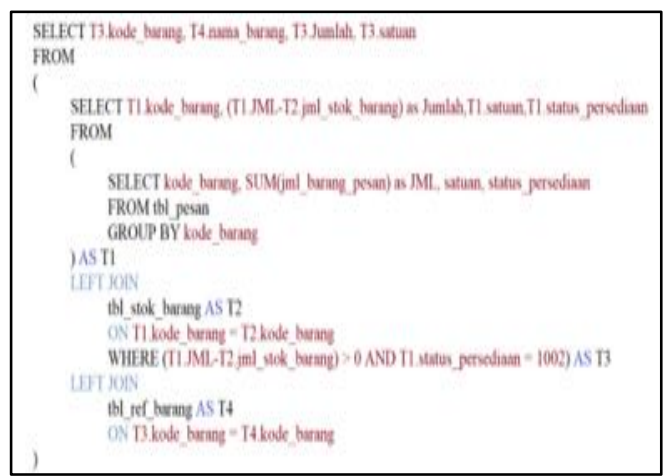

Gambar 17 Query daftar barang pesanan ke suplier 


\section{Implementasi Proses}

Implementasi pada aplikasi ini meliputi pengolahan data barang, pengolahan data pegawai, pengholahan harga barang, dan pengolahan permintaan barang

\section{Implementasi Output}

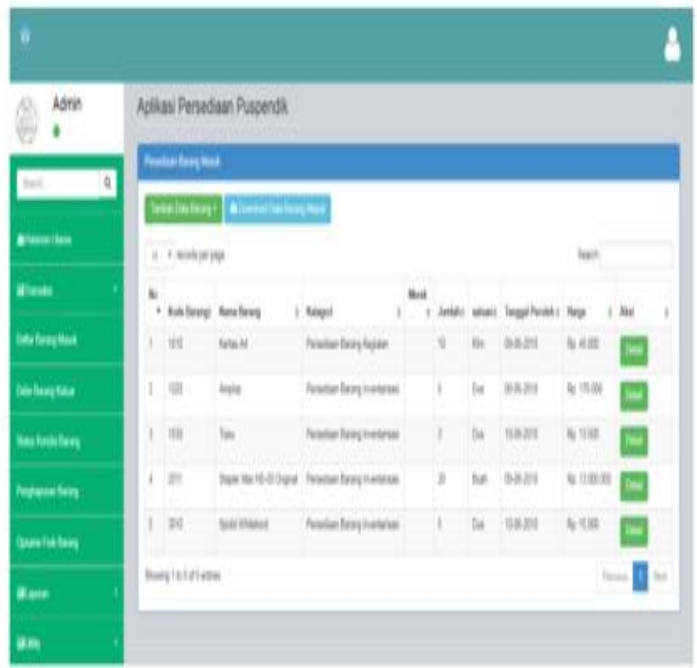

Gambar 18 Daftar barang masuk

Dari gambar 18 dapat lihat daftar barang yang masuk ke puspendik sehingga kita dapat melihat stok barang yang ada.

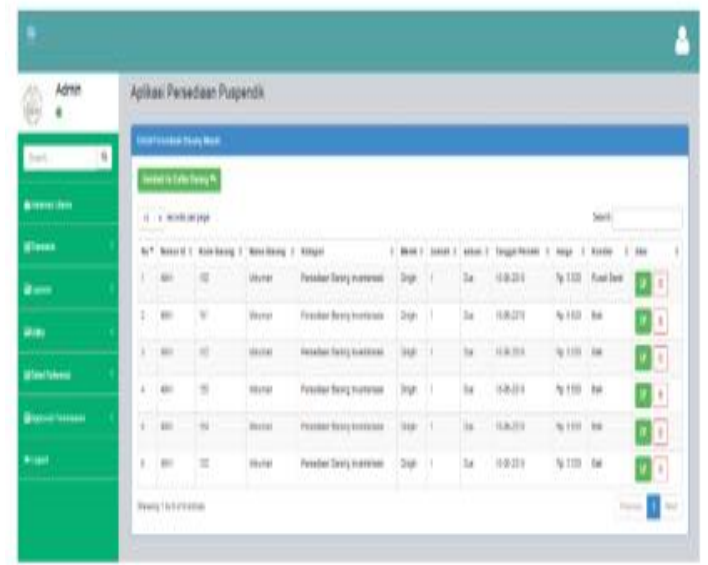

Gambar 19 Menu detail barang masuk

Dapat diperhatikan bahwa pada Gambar 19 dapat dilakukan pengecekan tentang, apakah barang dalam keadaan baik atau rusak?

Gambar 20, menampilkan data secara detail barang - barang yang mengalami kerusakan berat.

Dari gambar 21 dapat dilihat data pembelian barang yang sudah dibeli.

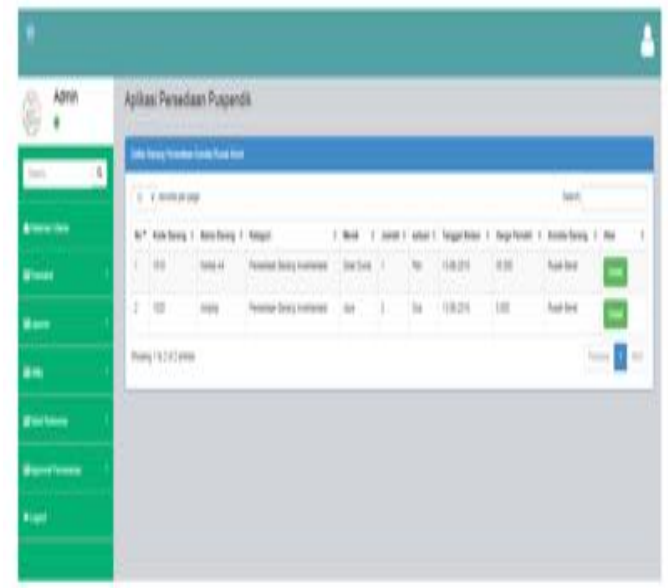

Gambar 20 Menu daftar barang rusak berat

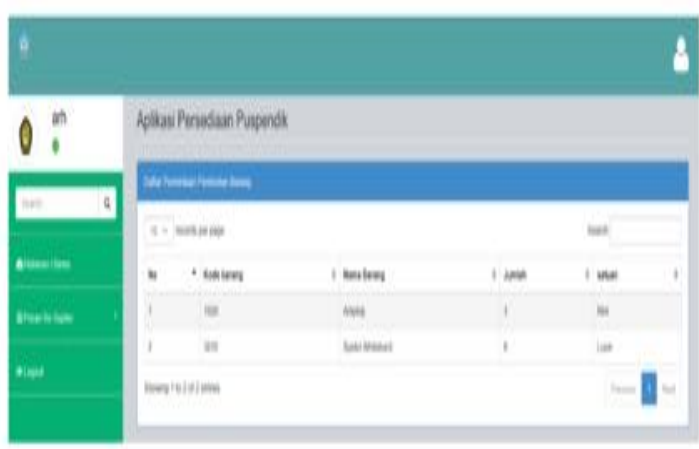

Gambar 21 Daftar permintaan pembelian barang

\section{Implementasi Input}

Pada Implementasi Input menampilkan menu utama admin yang bisa melakukan tambah, hapus dan ubah data. Untuk membedakan tampilan antara user menggunakan level hak akses dimana level 1 untuk admin, level 2 untuk penanggung jawab kegiatan (PJKT) dan level 4 untuk suplier.

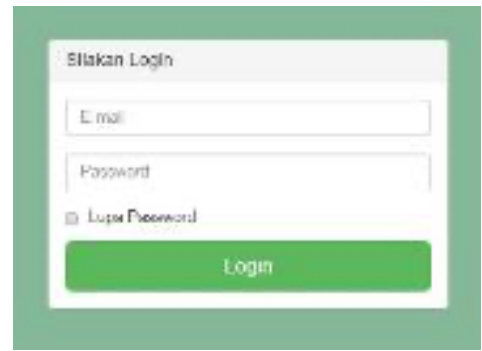

\section{Gambar 22 Menu login}

Gambar diatas menampilkan untuk login ke sistem yang akan digunakan. 


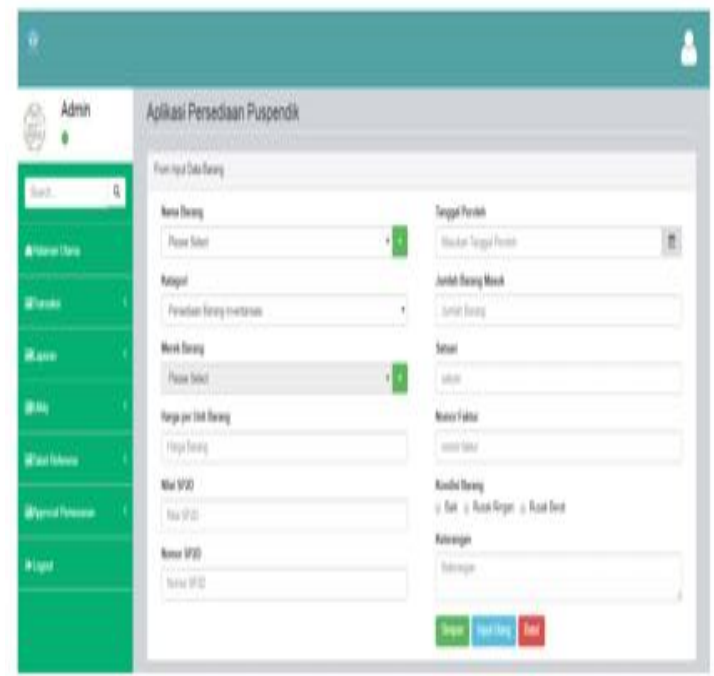

Gambar 23 Form input barang masuk

Dari gambar 23, dapat menginput barang yang akan masuk ke dalam persediaan barang dan kita dapat input pada saat masuk barang tersebut dalam keadaan rusak atau tidak.

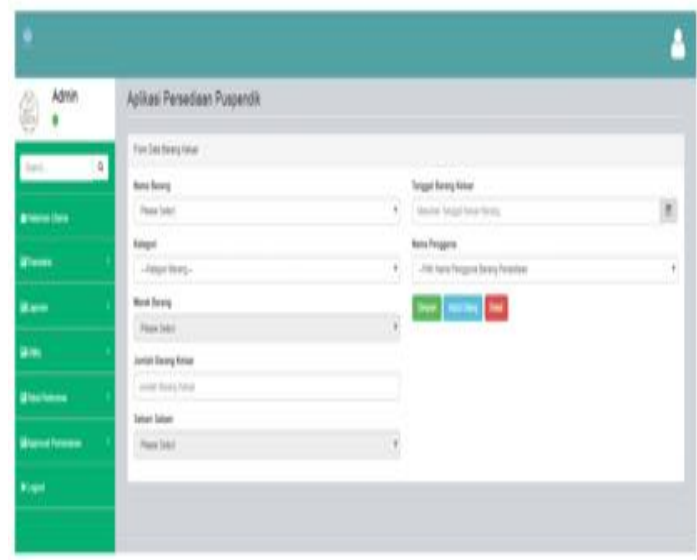

Gambar 24 Form tambah barang keluar

Gambar 24 ini, menerangkan tentang apabila barang keluar untuk dipergunakan maka akan ada menu tambah barang keluar.

Persediaan barang yang ada dapat dilihat dari menu pada Gambar 25, berdasarkan stok barang dapat dilihat berapa yang masuk dan berapa yang keluar.

Setelah laporan dilihat dengan menu form (pada Gambar 26) maka laporan tersebut dapat di cetak untuk dilaporkan kepada pimpinan mengenai persediaan barang yang ada.

\section{Persediaan}

Persediaan barang juga dapat kita lihat dari form laporan neraca barang (Gambar 27), sehingga kita dapat mengetahui berapa barang yang tersedia.

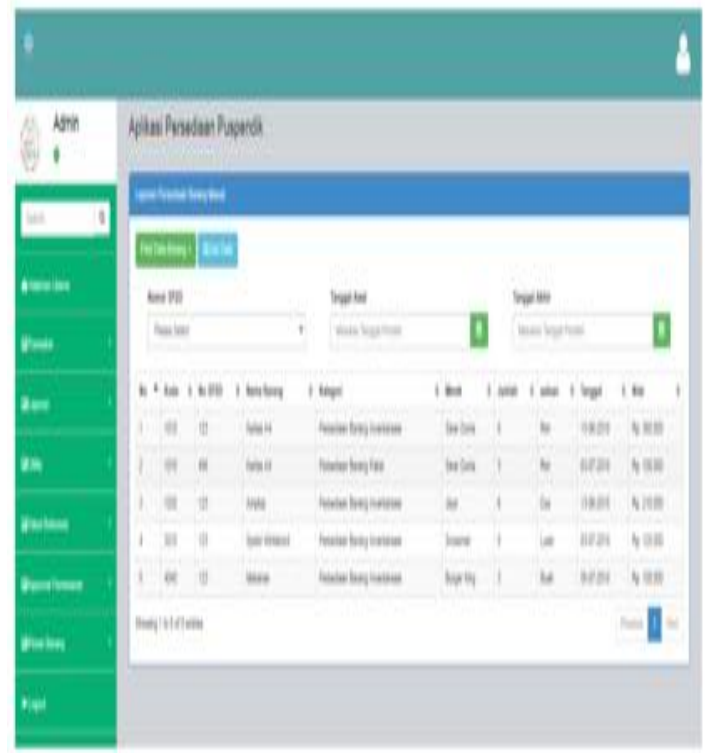

Gambar 25 Laporan barang persediaan masuk

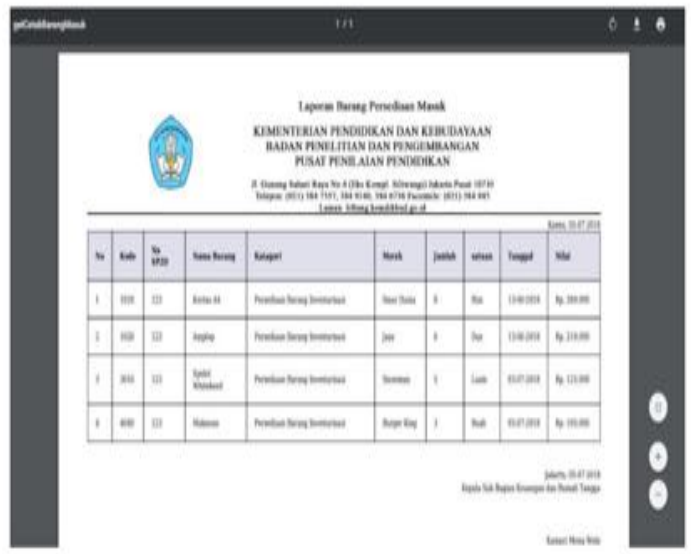

Gambar 26 Cetak laporan barang persediaan masuk

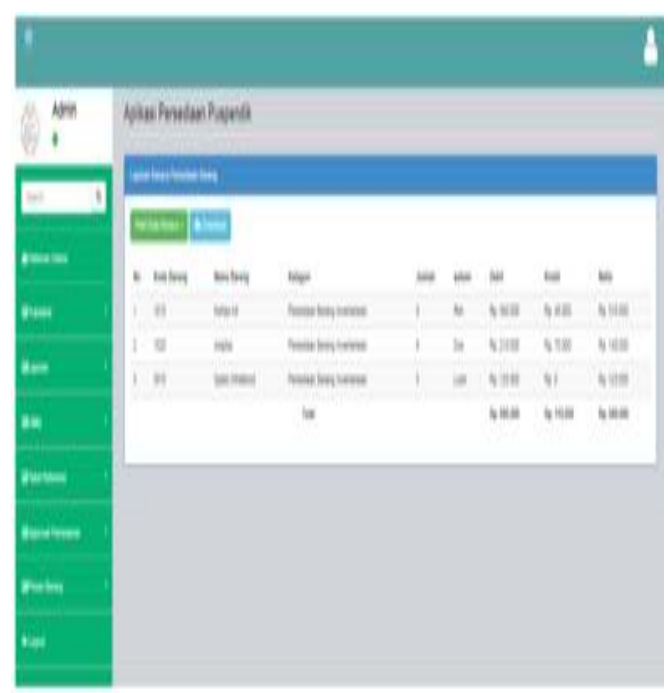

Gambar 27 Form laporan neraca barang 


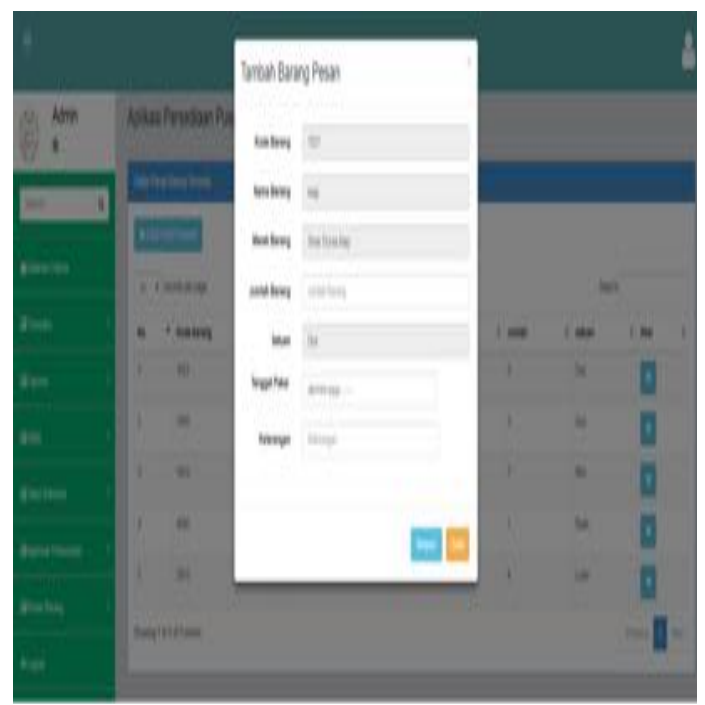

Gambar 28 Tambah barang pesanan

Selain itu juga dapat menambah barang pesanan sesuai dengan kebutuhan yang ada, berdasarkan form tambahan barang pesanan seperti pada Gambar 28.

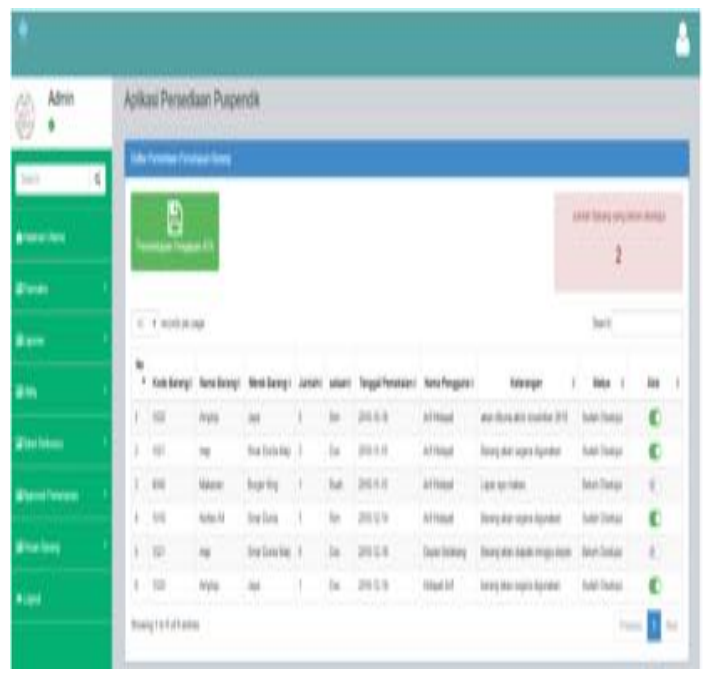

Gambar 29 Approval Pemesanan Barang

\section{Implementasi Menu}

Kemudian pesanan disetujui oleh pimpinan yang terkait bahwa barang setuju untuk dipesan berdasarkan Gambar 29.

\section{SIMPULAN}

Berdasarkan pengujian terhadap aplikasi sistem informasi ini yang telah dilakukan, didapat beberapa kesimpulan sebagai berikut :

1) Aplikasi yang dibangun mempermudah dalam proses permintaan dan pemberian barang persediaan kepada pengguna barang persediaan di Lingkungan Pusat Penilaian Pendidikan sehingga mendukung pengeloaan barang menjadi lebih baik.

2) Memudahkan dalam pembuatan laporan barang persediaan di lingkungan Pusat Penilaian Pendidikan.

3) Dalam implementasi ini penggunaan sistem lama dengan sistem baru dapat digunakan secara bersamaan sehingga dalam kurun waktu tertentu sistem lama dapat ditinggalkan.

4) Sistem informasi pengeloaan persediaan barang ini berhasil melakukan pengolahan data barang persediaan barang.

5) Dengan adanya sistem informasi ini dapat dilakukan back up data untuk menjaga data yang hilang atau yang rusak sehingga tidak terlalu mengganggu kinerja di Lingkungan Pusat Penilaian Pendidikan.

\section{DAFTAR PUSTAKA}

Anggi Listiani \& Sulistya Dewi Wahyuningsih 2016, Analisis Pengelolaan persediaan Barang Dagang untuk Mengoptimalkan Laba, Jurnal Peta Vol. 4 No 1, 95-103

Ar Khorida \& Wiwin Septiana 2017, Analisis Perencanaan dan Pengendalian Persediaan Barang Jadi Pada PT.Pardic Jaya Chemicals, Balance Vocation Accounting Journal, Vol 1

Assuari Sofyan. 2018. Manajemen Produksi dan Operasi. Depok: Penerbit Lembaga Fakultas Ekonomi Universitas Indonesia

Dewanti \& Trivoni 2014, MANAJEMEN PERSEDIAAN PADA PERUSAHAAN BAJA RINGAN DI YOGYAKARTA Studi Kasus CV. Segitiga Yogyakarta. Jurnal Magister Teknik Sipil. p.1-15

Harjanto Eddy. 2015. Manajemen Operasi Edisi Tiga. Bandung: Penerbit Grasindo

Heizer Jay, Render Barry. 2015. Manajemen Operasi - Manajemen Keberlangsungan dan Rantai Pasokan Edisi II. Jakarta: Penerbit Salemba Empat

Kadi Abdul. 2014. Pengenalan Sistem Informasi Edisi Revisi. Yogyakarta: Penerbit CV. Andi Offset

Kementerian Keuangan Republik Indonesia. 2016. Peraturan Menteri Keuangan Repoblik Indonesia Nomor 118/PMK.06/2016 Tentang Penatausahaan Barang Milik Negara. Jakarta: Kementerian Keuangan 
McLeod Raymond Jr. 2008. Sistem Informasi Manajemen. Jakarta: Salemba Empat.

Mudjahidin, \& Putra, N. P. 2010. Rancang Bangun Sistem Informasi Monitoring Perkembangan Proyek Berbasis Web Studi Kasus Di Dinas Bina Marga dan Pemantusan. Jurnal Teknik Industri Vol.11 No.1, 75-83.

Prawirosentono Suyadi. 2007. Manajemen Operasi: Analisi dan Studi Kasus. Jakarta: PT. Bumi Aksara

Ristono Agus. 2013. Manajemen Persediaan. Yogyakarta: Penerbit Graha Ilmu

Rusdiana, Irfan Moch. 2014. Sistem Informasi Manajemen. Bandung: Penerbit CV Pusaka Setia

Susanto Azhar. 2013. Sistem Informasi Akutansi dan Sistem Informasi Manajemen. Bandung: Lingga Jaya

Yuyus Dwi Kusuma Wardana 2016, Analisa sistem Pengelolaan Persediaan Barang Dagangan dan Pembelian Barang dagangan. Jurnal Peta Vol 1 no 1, 4053. 